\title{
Does Kenya's Development-Induced Displacement, and Resettlement Policy Match International Standards? A Gap Analysis and Recommendations
}

\author{
Antony Kamakia ${ }^{1,2}$, Shi Guoqing ${ }^{1,3} \&$ Mohammad Zaman ${ }^{1,3}$ \\ ${ }^{1}$ National Research Centre for Resettlement, Hohai University, China \\ ${ }^{2}$ Centre for Leadership and Policy, Kenya School of Government, Kenya \\ ${ }^{3}$ International Resettlement Specialists \\ Correspondence: Antony Kamakia, National Research Centre for Resettlement, Hohai University, 8 Focheng \\ West Road, Jiangning District 211100, Nanjing, Jiangsu, China. Tel: 86-151-9575-0064. E-mail: \\ antony.kamakia@hhu.edu.cn; antony.kamakia@ksg.ac.ke
}

Received: July 22, 2017

doi:10.5539/jsd.v10n5p162
Accepted: August 28, $2017 \quad$ Online Published: September 29, 2017

URL: https://doi.org/10.5539/jsd.v10n5p162

\begin{abstract}
Multilateral Development Finance Institutions (DFIs) apply variable Development-induced displacement and resettlement (DIDR) policies for project investment-finance extended to client countries. However, developing countries, in essence, finance their development or investment projects separately, thus the need for a DIDR policy that matches international safeguard standards. Kenya has recently enacted far-reaching improvements in its DIDR framework informed by a long history of controversies surrounding DIDR and the colonial displacement and resettlement praxis. This paper traces the development of DIDR framework in Kenya and then develops a matrix to compare the framework with international safeguards extracted from the standards of six selected multilateral DFIs. It then analyses the gaps and prescribes measures to bridge the gaps towards the international standards. The major gaps noted are lack of solid income and livelihood restoration mechanisms and inadequate tracking, supervision and monitoring for DIDR. It has also presented a discussion on the need to fast-track attainment of the international standards, particularly in this period when Kenya is embarking on 'Vision 2030' development blueprint which hopes to spur Kenya to "High-Income Country" status by the year 2030. Multilateral DFIs are also piloting new Environmental and Social Frameworks (ESF) with the objective of assisting individual countries scale-up their DIDR policy. They can start by supporting Kenya to bridge the gaps as well as building human and technological capacity. Policy aspects indicated in this paper will enhance DIDR outcomes for Kenya.
\end{abstract}

Keywords: development policy, involuntary resettlement policy, social safeguard standards, social impact assessment, resettlement action plan

\section{Introduction and Overview}

Globally, there is a marked acceleration of development projects as countries endeavor to grow the economy, modernize and raise the standards of living for the citizenry. The global agenda for development has been further advanced by multilateral development lenders such as the World Bank (WB) and African Development Bank (AfDB), Public Private Participation (PPP) models advocated by the new development paradigms (World Bank, 2013b; Ke et al., 2010) and new technologies such as plan for future green cities (Safransky, 2014). Also, there is the infusion of Chinese development finance in many initiatives such as the China-Africa Development Fund. The onset of the new multilateral development finance institutions such as the Asian Infrastructure Investment Bank (AIIB) and New Development Bank (NDB) has also complemented the existing multilateral development lenders and enhanced development cooperation (Kathrin, 2016). Many countries have different legal provisions, which invoke compulsory land acquisition for public projects, but development projects have the inevitable consequence of displacing and resettling populations. However, not all countries have solid frameworks for DIDR and post - resettlement support (PRS) that are concurrent with the internationally accepted standards.

International safeguard standards began to adopt in many DIDR policies of several countries such as India (GOI, 2013) and Kenya (GOK, 2009). For these countries, disputes, conflicts and protracted litigations arising from 
development and resettlement projects presented major setbacks and sabotage for sustainable development. Also, the World bodies such as United Nations (UN) have been propagating for sustainable development models that link to their mandates as global promoters of human rights and inclusive development. Countries, where there have been most controversies in DIDR, are the same countries that have embraced international safeguard standards much faster. The progress of DIDR policy in India, for instance, was shaped by controversies surrounding the development of the Sardar Sarovar-Narmada dam, one of the biggest dams in the World ${ }^{1}$.

In Kenya, the evolution of the DIDR framework was triggered by a series of temporary commissions of inquiry precipitated by controversies arising from a history of resettlement injustices and court-NGOs induced project delays. The Kenyan Government then instituted far-reaching reforms to its land acquisition and DIDR framework that culminated in the development of NLP in 2009 (GOK, 2009), the Land Act of 2012 (GOK, 2012b) $)^{2}$, NLC Act of 2012 (GOK, 2012c) $)^{3}$ and the Community Land Act of 2016 (GOK, 2016a). These policy and legal frameworks have been a major step towards the attainment of international standards in DIDR. The safeguards on DIDR are further contained and insulated by Chapter Five of the new Constitution of Kenya 2010 (GOK, 2010) and supplemented by amendments to the Environmental Management and Coordination Act (GOK, 2015a). Despite recent policy improvements, Kenya has not yet attained the complete international principles and benchmarks with regards to social impact assessments, DIDR management and practices.

The purpose of this paper is to provide a gap analysis between Kenya and the international safeguard standards for DIDR. The paper traces the history, practices and the development of the DIDR safeguards policy and standards in Kenya. It then proceeds to analyze the safeguard standards of six key DFIs to harness the consolidated international safeguard standards in DIDR. The DFIs considered are the WB, AfDB, the International Finance Corporation (IFC,) Asian Development Bank (ADB), Development Assistance Committee of the OECD (DAC-OECD) and Japan International Cooperation Agency (JICA). The international safeguard standards derived are then examined against the key safeguard provisions in Kenya as contained in the National Land Policy 2009, the Constitution of Kenya 2010, the Environmental Management and Coordination Amendment Act 2015 and the Land Amendment Act 2016 among others. For easier reference by the readers, a summary comparison matrix is derived. The paper then offers the measures to bridge the gaps towards the international safeguard standards.

\section{An Historical Narrative for Land and Resettlement in Kenya}

Displacement and Resettlement are not a new phenomenon in Kenya. After the Berlin Conference of 1898, European colonization accelerated, and Africa got partitioned with the plan of appropriating raw materials for the colonial powers. After the partitioning, the colonial authorities encouraged white settlements in the colonies by promoting large commercial agricultural farming and also to ease pressure on the burgeoning population in Western Countries at the time ${ }^{4}$. Kenya became a protectorate under the British East African Protectorate. The East African Lands Order of 1901 empowered the Commissioner of the Protectorate to alienate all land in Kenya to the British crown including the 10Mile coastal strip that had been under the Sultan of Zanzibar and had earlier been a product of another agreement by the British with the Sultan in 1895 (Mwaruvie, 2011). European settlers trooped to Kenya, displaced and resettled many native populations from the fertile white highlands to the less fertile lands. Indigenous communities such as the Kikuyu, Nandi, and Maasai were displaced and relocated to the less fertile land known as 'Native Reserves.' Displacement and resettlement of indigenous populations in Kenya continued to get effected through crown land ordinances, agreements, and treaties. To ensure the success of white commercial-agricultural farming, the Colonial Government introduced policies such as the "Kipande identity cards" to confine natives to the reserves and 'hut taxes.' These policies specifically ensured that the natives had to work in white settler farms so as to pay tax obligations to the Colonial Government (Elkins, 2000). Various Crown land ordinances were legislated in 1902, 1908, 1915, 1919, 1920 and 1921 to attract new white settlers to Kenya. The certificate of occupancy of land was also elevated to the certificate of ownership with 999-year-old leases for commercial agricultural production and 99-year leases for urban plots of land (Munubi et al., 2016). After British victory in the First World War, there was an additional influx of war veterans to Kenya, and a Soldier Settlement Scheme became established for them in Nanyuki, Kenya. There was a native uprising against the the British, starting from the 1940s, dubbed the MAUMAU. MAUMAU had begun its formation with the objective of fighting for their land that had forcibly remained alienated. To avoid such claims of

\footnotetext{
${ }^{1}$ http://nweb90.worldbank.org/oed/oeddoclib.nsf/DocUNIDViewForJavaSearch/12A795722EA20F6E852567F5005D8933

${ }^{2}$ Amended in 2016

${ }^{3}$ Revised Edition 2014 (2012)

${ }^{4}$ https://softkenya.com/kenya/land-in-kenya/
} 
dispossession of land by the native peoples, the colonial Government enacted the land control ordinance of 1959 that ensured that the natives bore no claims to appropriated land, especially for the MAUMAU insurgents. The colonial government later introduced the Registered Land Act of 1960 that allowed the natives to hold land titles, but the land conflicts still ensued (Presley, 1988).

Kenya got independence in 1963, and the present white settlements occupation and justification for native displacement and resettlement became legitimized. The various ordinances were not reviewed but rather entrenched in the first Constitution of Kenya of 1963. The supremacy of the title certificate stood unchallenged. The independent Kenyan Government realized that many African native populations had been displaced by white settlers and thus launched Resettlement schemes christened as the "Million Acre Resettlement" Scheme 5 . The Independent Kenyan Government got loans from the World Bank, Commonwealth Development Corporation (CDC) and the British Government to buy back land from the white settlers in the fertile highlands to resettle the natives on a willing buyer - willing seller basis. Many white settlers relocated to other hospitable British colonies in Africa. Land resettlement programs created a total of 123 state resettlement schemes, which had resettled about half a million, people by 1970 (Furedi, 1989). By 2005, 453 resettlement schemes had been established in Kenya but have not been sustainable due to income installation and restoration mechanisms. Many families subdivided land and sold to other people. Also, these state-financed resettlement schemes later became hijacked by the political elite who accorded priority to resettling their community members ${ }^{6}$, without due regard to stakeholder and political consultation hence intense conflicts. Many elites also appropriated huge chunks of land for themselves rather than the poor resettles. Resettlement schemes then became synonymous to uncertainty and serving self-interests of the ruling class.

During the 1980s also, there had been a policy expansion from resettlement schemes to projects such as roads, irrigation, and dams to boost the economy upwards and fight poverty. Kamburu Dam (1971-74) and Masinga Dam (1978-81) both displaced over 1000 families and in Kiambere Dam (1983-87) 6500 PAPs were displaced and relocated (Mburugu, 1994). The most important instrument for compulsory land acquisition and resettlement in Kenya was the Land Acquisition Act (Cap 295) of 1968, which was enacted to operationalize Article 75 of the 1963 Constitution. Socio-economic dynamics and livelihood restoration for PAPs, which are key safeguard standards, were not addressed or given the prominence they deserved. Resettlement was also carried out by different Government agencies in Kenya, which caused compensation after the project commenced, and without guarantees by formal instruments. Citizens had come to mistrust all resettlement schemes by the Government as DIDR was conducted simultaneously with the colonial legacy resettlement schemes. For PAPs without legitimate deeds to ownership including ancestral community land, forceful eviction using police force was invoked. Development projects in Kenya that have gotten mired in various controversies includes Kamburu, Masinga and Kiambere Dam Projects (Mburugu, 1994); Soda ash mining in Magadi (Hughes, 2008) and Third Nairobi Water in Nairobi County (Syagga and Olima, 1996). These are in addition to the Titanium Mining in Kwale County (Abuya, 2013) and the Mau Forest Complex (Langat, 2015). These controversies ranged from uncertainty \& mistrust, land tenure challenges, prolonged court cases, inconsistent \& inadequate compensation and socio-political intrigues mainly due to the perceived lack of income \& livelihood restoration hence opposition to the projects. Land and resettlement-related conflicts have also characterized historical resettlement and DIDR injustices. Such conflicts have been rampant in Kenya, and 32 conflicts occurred from 1965 to 1989, 45 conflicts experienced from 1990 to 1999, and 67 conflicts from 2000 to 2004 (Yamano and Deininger, 2005; Boone, 2011). The politicization of issues such as past resettlement injustices and land-resource rights were usually the catalyst of the conflicts.

Due to the various controversies regarding displacement and resettlement, the Government of Kenya responded by forming temporary commissions of inquiry to craft and recommend solutions. The commissions looked at various socio -economic and cultural issues in the history and practice of displacement and resettlement in Kenya with the purpose of coming up with a comprehensive legal and policy framework. These commissions have been the Akiwumi Commission of 1998, Njonjo Commission of 1999, Ndungu Commission of 2003 and Waki Commission of 2008. The various Commission reports culminated in the crafting of the land acquisition and DIDR framework in Kenya (NLP of 2009) and the subsequent Land Act of 2012, NLC Act of 2012 and the Community Land Act of 2016 (Munubi et al., 2016; GOK, 2016a).

\footnotetext{
${ }^{5}$ The Kenyan Government through the settlement Funds Trustee sought to resettle the displaced landless people and every District (now Sub-County) had a squatter selection committee chaired by the District Commissioner. The Committee would forward a list of landless squatters to the National Director of Lands and Settlements who would allocate land in identified Government Resettlement schemes.

${ }^{6}$ At the expense of other host communities who also were in dire need of resettlement
} 


\section{The Policy and Legal Framework for DIDR in Kenya}

The Sessional Paper No. 3 of 2009 on National Land Policy (NLP) provided the main directions for DIDR framework in Kenya. The policy was adopted by Parliament in 2009 after a lengthy interrogation period which started in 2004. Sections 175, 178, 193, 196, 197, 200, 208209 and 211 of the NLP capture resettlement as a special land issue requiring particular attention by Government. The policy identified the main challenges for all PAPs including those without legal rights and then proposed containment mechanisms (GOK, 2009). These mechanisms then became entrenched in Chapter Five of the new Kenyan Constitution of 2010. Article 67 and 68 of the Constitution operationalises the NLP through the enactment of new legislation on land, including compulsory land acquisition (GOK, 2012b) ${ }^{7}$ and the institutional framework for DIDR by the National Land Commission (GOK, 2012c). Article 60 of the Constitution further requires the National Land Policy, the Land Act and the National Land Commission Acts to be regularly revised.

The Land Act operationalised the NLP and consolidated and rationalized all Land Laws in Kenya with effect from $2012^{8}$. The act formally lays the institutional framework for NLC to deal with matters of compulsory land acquisition and compensation in Kenya for PAPs with legal rights, on behalf of all Government agencies. The Land Settlement Fund (LSF) trustees under National Government, is mandated to resettle victims of colonial injustices and PAPs without legal entitlement from land-banks appropriated and secured by NLC for this purpose. The transfer and sale of such land for this category of PAPs ${ }^{9}$ stand forbidden except under succession. Section 231 of the Land Act also advances the establishment of a Center for Policy Research and Development on all land related issues including DIDR. The policy and legal framework relating to compulsory land acquisition and DIDR in Kenya is complemented by the requirements for Environmental and Social Impact Assessment (ESIA) under the Environmental Management and Coordination Act of $1999^{10}$ (GOK, 2012a; GOK, 2015b).

\section{Gap Analysis with International Safeguard Standards}

DIDR safeguards championed by the Multi-lateral DFIs position as international safeguard standards, in ensuring that social and community concerns become factored in the design and implementation of development and investment projects. Scenarios, where developing countries have advanced DIDR safeguard standards than multi-lateral DFIs, are rare. Thus, the policies of DFIs prevail in projects financed by them. These DFIs finance various projects that change patterns of use of land, water, and other natural resources and cause a range of DIDR effects. Such projects trigger the application of sustainable social safeguards that also support the mandates of these institutions. The broad principles of all the DFI policies are similar, but project-processing benchmarks and post-resettlement support guidelines have minimal variations.

A corresponding matrix of social safeguards and resettlement policies of six DFIs, having a diversified portfolio of projects globally was first derived and the highest standards extracted (World Bank, 2013a; AfDB, 2013; ADB, 2009; IFC, 2012; OECD, 1992; JBIC, 2012). The over-arching safeguard standards are then compared against provisions in Kenyan legal and policy frameworks, and the gaps clearly analyzed in Table1 and Table2 Matrices below. The Kenyan laws and policies perused are those directed towards DIDR, ESIA, and RAP. These are the National Land Policy of Kenya -NLP (GOK, 2009), Environmental Management and Coordination and Amendment (EMCA) Act (GOK, 2015a), the Community Lands Act (GOK, 2016a) and the Land (2012) \& Amendment Act 2016 (GOK, 2016b).

\footnotetext{
${ }^{7}$ The Land Act of 2012 was further amended in 2016 and strengthened the DIDR framework.

${ }^{8}$ The former legal acts were at times contradicting each other. The Act repealed the Indian transfer of property Act of 1882, The Governments Lands Act (cap 280); the Way leaves Act (cap 292) and the Land Acquisition Act (cap 295).

${ }^{9}$ Without formal rights and entitlement

${ }^{10}$ Revised edition 2012 (1999), amended in 2015
} 
Table 1. Principles of DIDR policy

\begin{tabular}{|c|c|c|c|}
\hline Principle & International standards & Kenyan Laws & Gaps and Recommendations \\
\hline $\begin{array}{l}\text { Avoid, } \\
\text { minimize or } \\
\text { mitigate DIDR; } \\
\text { Prepare } \\
\text { mitigation } \\
\text { plans for the } \\
\text { PAPs }\end{array}$ & $\begin{array}{l}\text { Avoid or minimize DIDR by } \\
\text { exploring various project designs. } \\
\text { If it is not feasible to avoid } \\
\text { resettlement, explore all social } \\
\text { impacts whether PAPs are } \\
\text { required to move or not or move } \\
\text { voluntarily; Provide full } \\
\text { compensation at replacement } \\
\text { costs or support allowances for } \\
\text { all PAPs before the project } \\
\text { commences unless under special } \\
\text { circumstances. }\end{array}$ & $\begin{array}{l}\text { The laws provide for feasibility study } \\
\text { and avoidance of DIDR wherever } \\
\text { feasible through the integrated } \\
\text { environmental, social, economic and } \\
\text { cultural impact assessment and } \\
\text { community development plans for all } \\
\text { DIDR projects, preceding operational } \\
\text { license by NEMA. The NLC and } \\
\text { LSF trustees facilitate land } \\
\text { acquisition and resettlement for all } \\
\text { DIDR projects }{ }^{11} \text {. }\end{array}$ & $\begin{array}{l}\text { There is no clear commitment for } \\
\text { sustainable resettlement mechanisms. The } \\
\text { laws can be amended to include adequate } \\
\text { provision for such. The laws should also } \\
\text { provide compensation at replacement costs } \\
\text { and exempt DIDR from the depreciation } \\
\text { valuation as factored in other Kenyan laws; } \\
\text { NEMA and NLC should then enact } \\
\text { comprehensive SIA and RAP guidelines } \\
\text { and regulations. A special directorate for } \\
\text { SIA should be incorporated in NEMA to } \\
\text { screen SIA independently from EIA. }\end{array}$ \\
\hline
\end{tabular}

Ensure adequate consultation, participation and grievance redress mechanisms with the principal stakeholders including PAPs, NGOs, politicians and

Involve and consult with all stakeholders

\section{pro} professionals and host communities: Provide informational resources such as DIDR office, booklets, brochures, pamphlets or website and grievance redress mechanisms

\begin{tabular}{ll}
\hline & $\begin{array}{l}\text { Disclose RAP to the PAPs, key } \\
\text { Disclose } \\
\text { mitigation } \\
\text { measures for } \\
\text { DIDR; } \\
\text { comments; Resettlement with } \\
\text { Support and } \\
\text { improve PAPs } \\
\text { encouraged i.e. supporting } \\
\text { and hosts' } \\
\text { economic, } \\
\text { livelihood restoration and the } \\
\text { existing economic, social and } \\
\text { cultural and } \\
\text { institutions. }\end{array}$ \\
$\begin{array}{l}\text { cultural institutions of PAPs and } \\
\text { their hosts to the greatest extent } \\
\text { possible; Enhance sustainable } \\
\text { outcomes along the lens of } \\
\text { gender and vulnerable groups. }\end{array}$
\end{tabular}

The Constitution of Kenya, Land Act, and Community Land Act and ESIA guidelines provide for stakeholders' consultation and involvement in the resettlement and grievance redress committees ${ }^{12}$.
The provisions for informational resources and grievance redress are inadequate. The envisaged SIA and RAP guidelines and regulations can include the pertinent details including internet-based platforms or phone APP.
The laws provide for the publication of summary ESIA and RAP report in the Kenya Gazette or two newspapers of wide circulation preceding the issue of license so as to seek public views. The laws also recognize gender and socio-culture rights of all communities in Kenya and protect outcomes for vulnerable groups in DIDR. 2/3 majority vote must sanction the Community Development Plans for investments in the rural communities ${ }^{13}$.
There is no clear commitment for sustainable RwD and livelihood restoration in the Kenyan DIDR framework. In practice, compensation is the overriding strategy as opposed to long-term or sustainable livelihood rehabilitation. The envisaged SIA and RAP guidelines should include pertinent procedures and strategies for RwD for PAPs and hosts in separate rural and urban settings.

\footnotetext{
${ }^{11}$ Section 9 and Part VI of the Environmental Management and Co-ordination Act, Section 5 of the National Land Commission Act, Sections $107,110,111,113,114,115,117,119,122,124, \&$ 134, 144, 146 of the Land Act , Article 40 of the Constitution, Section $5 \& 6$ of the Community Land Act and Section 3 of the Mining Act. The Community Land Act and Mining Act also introduce Benefit-sharing arrangements with rural indigenous communities in the afore-mentioned Community Development Plans.

${ }_{12}$ Section 21, 30, 40 of the Community Land Act, Section 134 of the Land Act, Section 70 of the Environmental Management and Co-ordination Act and Section 194, 195, 196 and 197 of the National Land Policy

${ }^{13}$ Section 59 and 60 of the Environmental Management and Co-ordination Act, Section 157 of the Constitution, Section 89 of the Land Act, Section 21, 30, 36 of the Community Land Act.
} 
Table 2. Project processing benchmarks

\begin{tabular}{|c|c|c|c|}
\hline Principle & International Standards & Kenyan Laws & Gaps and Recommendations \\
\hline $\begin{array}{l}\text { Compatibility } \\
\text { with other } \\
\text { safeguard } \\
\text { frameworks }\end{array}$ & $\begin{array}{l}\text { Ensure compliance with } \\
\text { complementary policies such as } \\
\text { climate and biodiversity. }\end{array}$ & $\begin{array}{l}\text { Before license issuance, NEMA } \\
\text { purposes to seek comments of lead } \\
\text { agencies so as to ensure } \\
\text { conformance to other policy areas } \\
\text { such as climate }^{14} \text {. }\end{array}$ & $\begin{array}{l}\text { Adequately addressed by the current legal } \\
\text { and policy environment }\end{array}$ \\
\hline $\begin{array}{l}\text { DIDR scoping, } \\
\text { screening, } \\
\text { categorization } \\
\text { and RAP }\end{array}$ & $\begin{array}{l}\text { Identify all PAPs with or without } \\
\text { formal rights who have lost various } \\
\text { assets and livelihood; categorize } \\
\text { resettlement projects as per level of } \\
\text { risks involved. For sector operations } \\
\text { that involve DIDR, prepare sector } \\
\text { frameworks such as RPF or SESA; } \\
\text { RAP should have time-bound } \\
\text { actions, budgets and cut-off date in } \\
\text { line with RAP instruments and } \\
\text { templates. }\end{array}$ & $\begin{array}{l}\text { Public agencies in need of Land } \\
\text { acquisition inform and fulfill } \\
\text { thresholds of NLC. NLC publishes } \\
\text { a notice in the Kenya Gazette and } \\
\text { newspapers and then geofences } \\
\text { and prepares the RAP. NLC is } \\
\text { empowered to summon any person } \\
\text { to authenticate asset ownership; } \\
\text { Category of resettlement schemes } \\
\text { depicted as high risk by NEMA; } \\
\text { For sector operations, NEMA has } \\
\text { introduced new guidelines for } \\
\text { Strategic Environmental and Social } \\
\text { Impact Assessment (SESA) }{ }^{15} \text {. }\end{array}$ & $\begin{array}{l}\text { The envisaged SIA and RAP guidelines } \\
\text { can include varying provisions for } \\
\text { different DIDR instruments as per risk } \\
\text { levels and professional RAP templates in } \\
\text { line with international best practices; The } \\
\text { law should also make it mandatory for } \\
\text { NEMA-SIA officers to be members of } \\
\text { RAP implementation committees so as to } \\
\text { enhance DIDR outcomes. }\end{array}$ \\
\hline $\begin{array}{l}\text { Supervision, } \\
\text { monitoring, } \\
\text { and evaluation }\end{array}$ & $\begin{array}{l}\text { Tracking, audit, supervision, } \\
\text { monitoring and evaluation to } \\
\text { determine compliance with the } \\
\text { objectives' and principles; Public } \\
\text { access to ESIA and RAP in the } \\
\text { website; Institutionalize the practice } \\
\text { of internal and external/international } \\
\text { monitoring and evaluation through } \\
\text { real-time web-platforms. }\end{array}$ & $\begin{array}{l}\text { EMCA provides for independent } \\
\text { internal audits by the project } \\
\text { developer and externally by the } \\
\text { community; EMCA has also set } \\
\text { additional mechanisms such as the } \\
\text { standards and enforcement } \\
\text { committee of NEMA, } \\
\text { complemented by the National } \\
\text { Environment Tribunal and the } \\
\text { Land and Environment Court as a } \\
\text { last resort to arbitrate on ESMP \& } \\
\text { RAP issues }{ }^{16} \text {. The law requires } \\
\text { NEMA to host ESIA reports on } \\
\text { their website. }\end{array}$ & $\begin{array}{l}\text { In practice, monitoring for EIA is more } \\
\text { stringent as compared to SIA \& RAP. The } \\
\text { law should also oblige NEMA to host } \\
\text { RAP for public access on their website as } \\
\text { currently, it only hosts the ESIA reports. } \\
\text { The envisaged SIA Directorate in NEMA } \\
\text { should enhance and enforce annual audits } \\
\text { for DIDR schemes and also require NLC } \\
\text { to engage external/international } \\
\text { monitoring and evaluation experts who } \\
\text { report to NLC \& NEMA via a real-time } \\
\text { web- based platform. This platform can } \\
\text { also integrate the grievance redress service } \\
\text { or APP to cater for aggrieved PAPs or } \\
\text { public citizens. }\end{array}$ \\
\hline
\end{tabular}

\section{Discussion}

Over the years, Kenya has made significant progress with regards to the legal and policy frameworks for DIDR. The current framework has strived to contain the international safeguard standards and further create an institutional framework to manage and centralize DIDR in Kenya. The National Land Commission- NLC draws its powers directly from the Constitution of Kenya 2010 and is already demonstrating to be focused on its mandate for sustainable outcomes for DIDR. It has already initiated studies to evaluate past DIDR schemes with the aim of strengthening the DIDR framework (NLC, 2016). The NLC offers a "twin model for resettlement" where resettlement becomes an independent project from the Government agency triggering the DIDR. Experiences from DIDR practices worldwide shows that the twin model has enhanced and sustainable outcomes (Lindalen, 2012). Furthermore, all Government agencies in Kenya must write and deposit the project designs and fees to the NLC requesting to acquire land on their behalf. This application must satisfy NLC thresholds and article 40 of the Constitution. NLC is then required to publish a notice of the intention to acquire land in the

\footnotetext{
${ }^{14}$ Section 50 of the Environmental Management and Co-ordination Act

${ }^{15}$ Section 107, 111 of the Land Act, Section 5 of National Lands Commission Act, Section 107, 113 of the Land Act and Section 59 of Environmental Management and Co-ordination Amendment Act, Article 40 of the Constitution

${ }^{16}$ Section 59 and 125 of the Environment Management and Co-ordination Act; Section 36 of the Community Land Act
} 
Kenya Gazette or two newspapers of wide circulation in Kenya for anybody who appears to have interests in the land to be acquired. After 30days of notice, NLC constitutes inquiry, procures professional firms to undertake RAP, processes compensation and takes the full possession of land and assets. The state agency concerned then progresses to undertake civil and engineering phases of the development project. According to several in-depth interviews with NLC officials, instances when different Government agencies applied different DIDR standards and focused on engineering works at the expense of social safeguards, have been profoundly contained by the current DIDR framework. In case the public purpose that acquired the land fails to materialize, the NLC must offer land back to previous owners as a priority in a separate agreement. Further, NLC is the custodian of Land for all Government agencies, and only after payment of full compensation or negotiated resettlement, that it can possess the land and assets. However, the NLC may take temporary possession for a maximum period of 5years but pay compensation as appropriate, or deposit funds in interest earning account pending full possession. This phenomenon is line with international standards, where borrowers are required to deposit funds into an interest-earning escrow account in case of complex issues that make it impossible to pay before project initiates. Article 66 of the Constitution, section 12 of LA and section 3 of the Mining Act specifically, guard against exploitation of indigenous rural communities by the requirement that NLC must acquire land and resettle PAPs where minerals have been discovered. This also applies to land in zones earmarked for investment purposes such as Special Economic Zones, Technology Incubation Centers, and PPP investment models. The act also mandates the exchequer to share loyalties and revenues with the concerned communities where the investments are located. Section 177 of NLP further encourages the Government to establish land banks to assist in the progressive resettlement planning of PAPs without legal rights.

However, as depicted in Table 1 and 2 above, there are some noted weaknesses in the DIDR framework for Kenya. The main issues are the lack of commitment to sustainable income \& livelihood restoration mechanisms. The provision for Resettlement with Development (RWD) with a long-term perspective ${ }^{17}$ needs to become enjoined in policy and legal enhancements (Vanclay, 2017). This enhancement will only become realized by amending the EMCA and Land Acts and the enactment of comprehensive SIA and RAP regulations and guidelines such as the current noise or waste-disposal regulations of NEMA. The Land, Community land, and Mining Acts have various provisions for resettlement and community development plans in benefit-sharing arrangements but still a commitment to sustainable SISR schemes is grossly lacking. These sentiments were echoed during interviews with officials of key Government agencies that undertake massive DIDR projects in sectors such as roads, railway and hydropower in Kenya ${ }^{18}$. There is also the opportunity to partner with the private sector for the elusive component of post-resettlement supports such as preferential job-employment for PAPs. This partnership should get justified by the fact that, the benefits of development projects provide a multiplier effect to all sectors including the private sector. Indeed, the global corporations have also embraced sustainable development practices such as CSR as business operations without social considerations have become futile (GRI, 2016). The envisaged SIA and RAP guidelines can also include social protection mechanisms $^{19}$ such as social transfers, health and endowment insurance as the practice in China. Other social innovations can also be explored that assess the viability of resettlement as a climate adaptation and mitigation strategy and thereby access the vast global funds dedicated to addressing the global climate change agenda (Tadgell et al., 2017).

Generally speaking, DIDR dislocates communities in the quest for land, food, jobs and politics than communities who have occupied the same space for generations (Duverger, 2012). Income restoration, for instance, is the most elusive element in any resettlement policy. Compensation may enable PAPs to purchase new assets but does not guarantee income restoration components, and this poses risks to human rights and security in the long term (Price, 2009; Choi, 2013; Satiroglu and Choi, 2015). Livelihood restoration can also be prominent in the RAP, but may often disappear after the displacing project is complete (Koenig, 2009). The reproduction squeeze theory, the Impoverishment Risk and Reconstruction (IRR) and the sustainable livelihood models are some of the theoretical frameworks that analyze mechanisms through which poverty links to external shocks like involuntary resettlement (Bernstein, 1979; Bernstein, 1977; Cernea and McDowell, 2000). Unlike armed conflicts and natural disasters, DIDR does not present a direct threat. However, the threat lies in declining economic circumstances leading to the vulnerability of households (Terminski, 2013; Terminski, 2014). The goal of DIDR should always be sustainable outcomes as lack of social sustainability presents a threat to economic and

\footnotetext{
${ }^{17}$ Preferably exceeding 20 years

${ }^{18}$ We interviewed Key officials from Kenya Urban Roads Agency, National Environmental Management Agency (NEMA) and the National Land Commission (NLC).

${ }^{19}$ For vulnerable groups of PAPs such as the aged, orphans and disabled persons
} 
environmental sustainability. Incidences of criminality, overfishing, and farming on riparian reserves are clear examples of how the poor people survive when deprived of basic social needs. The Rio+20 and the UN Habitat World forum in Napoli 2012 and Medellin 2014 forums have all elevated sustainability models to the global agenda (Wikipedia, 2015a; New World Encyclopedia, 2015). The UN Assembly also adopted 17goals, and 169 targets referred to as sustainable development goals for 2016-2030 (United Nations, 2016). Kenya has lined up ambitious development projects contained in "Vision 2030" development blueprint in which it hopes to spur industrialization and accelerated economic growth during the period 2008-2030 (GOK, 2007). Sustainable resettlement for DIDR is, therefore, paramount to protect and expand the anticipated economic gains.

Inadequate tracking, supervision, monitoring and evaluation for DIDR were emerging weaknesses and confirmed by the various interviews. The Kenyan law provides for standards and enforcement committee of NEMA, and this committee should co-opt international DIDR specialists as members. The compliance directorate of NEMA should also enforce the legal requirement for annual ESIA and RAP monitoring and audit as currently only the requirements for annual Environmental audit are adequately monitored. The law should also be amended to oblige NLC to engage independent firms for audit, monitoring and evaluation and report directly to NEMA and NLC boards of management via an online web platform. Both NLC and NEMA also have directorates dealing with research, monitoring and evaluation and this can advance policy for DIDR in Kenya in collaboration with policy think-tanks such as the Kenya School of Government. Even for the Multilateral DFI safeguard policies, they evolve on evaluation research in various countries over time (AFDB, 2015; World Bank, 2015)

\section{Conclusion}

This paper has examined the DIDR safeguards and policy development in Kenya from a historical perspective culminating in the enactment of several safeguard standards in Kenya. It has then analyzed the gaps with the conventional international standards and offered recommendations. In total, the DIDR safeguards standards as compared to international standards are not wide and can condense in the future policy and legal enhancements. The transitory gaps are lack of sustainable livelihood rehabilitation mechanisms and the inadequate tracking, supervision and monitoring for DIDR in Kenya. In other words, advanced scientific DIDR management needs to be encased within the institutional frameworks for DIDR in Kenya. Development Finance Institutions such as African Development Bank and World Bank are piloting new Environmental and Social Frameworks (ESF) with the objective of assisting individual countries scale-up their DIDR policy and management. They can start by supporting Kenya to bridge the noted gaps as well as building human and technological capacity.

There is a reinvigorated political goodwill for displacement and resettlement in Kenya, compounded by the policy, legal and institutional frameworks, directed towards resolution of the historical injustices of colonial era. The Government, in collaboration with the NLC, has so far resettled an estimated 70,790 families in resettlement schemes covering 35,300 hectares in Lamu, Kilifi, Malindi and Kwale ${ }^{20}$. In January 2016, 7800 squatters residing in Waitiki farm, in the coastal city of Mombasa, Kenya were permenentlty resettled in the same farm, and the President personally presided over the handing-over ceremony (Tsuma and Mwakera, 2016). The Government has also cumulatively resettled an estimated 20,000 Internally Displaced Persons arising from land-resettlement related conflicts as at the end of 2016 (Openda, 2016) and an estimated 100,000 PAPs in DIDR projects throughout the country as from 2012. These practices continue to present assurance for sustainable development and citizens' trust for DIDR, at a time when such trust had eroded in the past. Further improvements in policy aspects indicated in this paper will strengthen the policy, legal and institutional frameworks.

\section{Acknowledgements}

The authors are profoundly grateful to the staff of the National Research Centre for Resettlement (NRCR) at Hohai University, China for providing vital academic support and assistance in the preparation of this paper.

\section{References}

Abuya, W. O. (2013). What is in a Coconut? An Ethnoecological Analysis of Mining, Social Displacement, Vulnerability, and Development in Rural Kenya. African Studies Quarterly, 14.

ADB. (2009). Safeguard Policy Statement ADB Policy Paper. June 2009 ed. Manilla, Phillipines: Asian Development Bank.

\footnotetext{
${ }^{20} \mathrm{http} / / /$ softkenya.com/kenya/land-in-kenya/
} 
AFDB. (2013). African Development Bank Group's Integrated Safeguards System - Policy statement and operational safeguards. In Division CaS (Ed.). Tunisia: African Development Bank.

AFDB. (2015). The African Development Bank's involuntary resettlement policy: Review of implementation. Assessment of the use of "Country Systems" for environmental and social safeguards and their implications for AfDB-financed operations in Africa, 1.

Bernstein, H. (1977). Notes on Capital and Peasantry. Review of African Political Economy, 4, 60-73. https://doi.org/10.1080/03056247708703339

Bernstein, H. (1979). African Peasantries: A theoretical Framework. The Journal of Peasant Studies, 6, 421-443. https://doi.org/10.1080/03066157908438084

Boone, C. (2011). Politically allocated land rights and the geography of electoral violence: The case of Kenya in the 1990s. Comparative Political Studies.

Cernea, M. M., \& McDowell, C. (2000) Risks and reconstruction: Experiences of resettlers and refugees. World Bank Publications. https://doi.org/10.1596/0-8213-4444-7

Choi, N. (2013). Displaced: the Human Cost of Development and Resettlement. Journal of Refugee Studies, 26, 604-605. https://doi.org/10.1093/jrs/fet037

Duverger, M. (2012). The study of politics. Springer Science \& Business Media.

Elkins, C. (2000). The struggle for mau mau rehabilitation in late colonial Kenya. International Journal of African Historical Studies, 25-57. https://doi.org/10.2307/220257

Furedi, F. (1989). The Mau Mau War in Perspective. London: James Currey.

GOI. (2013). The Right to Fair Compensation and Transparency in Land Acquistion, Rehabilitation and Resettlement Act. The Gazette of India.

GOK. (2007). Vision 2030 of Kenya. In Development MoPa (Ed.). Nairobi, Kenya: Government Printer.

GOK. (2009). Sessional Paper No. 3 on National Land Policy. No. 3 of 2009. Nairobi, Kenya: Ministry of Land, Housing and Urban Development.

GOK. (2010). The Constitution of Kenya. In Attorney General (Ed.) Revised Edition 2010 ed. Nairobi, Kenya: Government Printer.

GOK. (2012a). The Enviromental Management and Cordination Act, 1999. Retrieved from http://isk.or.ke/userfiles/proposed_emca_amendments.pdf

GOK. (2012b). The Land Act. In General A (Ed.). Revised Edition 2012 ed. Nairobi, Kenya: National Council for Law Reporting.

GOK. (2012c). The National Land Commission Act. In General TA (Ed.). CHAPTER 5D. Revised Edition 2014 [2012] ed. Nairobi, Kenya: National Council for Law Reporting.

GOK. (2015a). The Environmental Management and Coordination (1999) Amendment Act 2015. Acts No. 5 ed. Nairobi, Kenya: Government Printer.

GOK. (2015b). The Environmental Management and Coordination Amendment Act. No. 5 of 2015. Nairobi, Kenya: National Council for Law Reporting.

GOK. (2016a). The Community Land Act. In General A (Ed.). Kenya Gazette Supplement No. 148 (Acts No. 27). Nairobi, Kenya: Government Printer.

GOK. (2016b). The Land Amendment Act Kenya Gazette Supplement No. 149 (Acts No. 28). Special Issue ed. Nairobi, Kenya: Government Printer.

GRI. (2016). G4 Sustainability Reporting Guidelines. Retrieved from https://www.globalreporting.org/standards/g4/Pages/default.aspx

Hughes, L. (2008). Mining the Maasai Reserve: The Story of Magadi. Journal of Eastern African Studies, 2, 134-164. https://doi.org/10.1080/17531050701847326

IFC. (2012). Performance Standard 5: Land Acquisition and Involuntary Resettlement. Retrieved from http://www.ifc.org/wps/wcm/connect/3d82c70049a79073b82cfaa8c6a8312a/PS5_English_2012.pdf?MOD $=$ AJPERES 
JBIC. (2012). Guidelines For Confirmation of Environmental and Social Considerations. Retrieved from https://www.jbic.go.jp/wp-content/uploads/page/efforts/environment/confirm_en/pdf_01.pdf

Kathrin, B. (2016). New players with handicaps. Retrieved from https://www.dandc.eu/en/article/asian-infrastructure-investment-bank-aiib-and-new-development-bank-ndb -are-changing

Ke, Y., Wang, S., \& Chan, A. P. (2010). Risk allocation in public-private partnership infrastructure projects: comparative study. Journal of Infrastructure Systems, 16, 343-351. https://doi.org/10.1061/(ASCE)IS.1943-555X.0000030

Koenig, D. (2009). Urban relocation and resettlement: Distinctive problems, distinctive opportunities. In Oliver-Smith, A. (Ed.), Development and Dispossession: The Crisis of Development Forced Displacement and Resettlement. SAR Press, Santa Fe, NM: 119-139.

Langat, P. (2015) Mau Evictions. Retrieved from http://www.nation.co.ke/news/politics/Mau-eviction-WilliamRuto/-/1064/2743060/-9icmkv/index.html

Lindalen, T. (2012). A New House or a New Life?: A Case Study of Involuntary Resettlement in the South-North Water Transfer Project in Henan China.

Mburugu, E. K. (1994) Dislocation of settled communities in the development process: The case of Kiambere hydroelectric project. World Bank Technical Paper, 49-49.

Munubi, S. L., Mwangi, W., \& K'Akumu, O. (2016) Involuntary resettlement policy and praxis in Kenya: Conforming with the national land reforms. Journal of Basic and Applied Research, 16(4), 278-291.

Mwaruvie, J. (2011). The Ten Miles Coastal strip: An Examination of the Intricate Nature of Land Question at Kenyan Coast. International Journal of Humanities and Social Science, 1(20), 176-182.

New World Encyclopedia. (2015). Sustainable Development. Retrieved from http://www.newworldencyclopedia.org/p/index.php?title=Sustainable_development\&oldid=991812

NLC. (2016). Exploring the Status of Settlement Schemes in Kenya. In Lukalo F (Ed.). Nairobi, Kenya: National Lands Commision.

OECD. (1992). Guidelines for Aid Agencies on Involuntary Displacement and Resettlement in Development Projects. Retrieved from http://www.oecd.org/dac/environment-development/1887708.pdf

Openda, J. (2016). Govt to use Sh6bn to resettle over 90,000 integrated IDP. Daily Nation Newspaper. Nairobi, Kenya: Nation Media Group.

Presley, C. A. (1988). The Mau Mau rebellion, Kikuyu women, and social change. Canadian Journal of African Studies/La Revue canadienne des études africaines, 22, 502-527.

Price, S. (2009). Development and Dispossession: The Crisis of Forced Displacement and Resettlement. Asia Pacific Journal of Anthropology, 10, 364-366. https://doi.org/10.1080/14442210903281469

Safransky, S. (2014). Greening the urban frontier: Race, property, and resettlement in Detroit. Geoforum, 56, 237-248. https://doi.org/10.1016/j.geoforum.2014.06.003

Satiroglu, I., \& Choi, N. (2015). Development-Induced Displacement and Resettlement: New Perspectives on Persisting Problems. Routledge.

Syagga, P. M., \& Olima, W. (1996). The impact of compulsory land acquisition on displaced households: The case of the Third Nairobi Water Supply Project, Kenya. Habitat International, 20, 61-75. https://doi.org/10.1016/0197-3975(95)00034-8

Tadgell, A., Doberstein, B., \& Mortsch, L. (2017). Principles for climate-related resettlement of informal settlements in less developed nations: a review of resettlement literature and institutional guidelines. Climate and Development, 1-14. https://doi.org/10.1080/17565529.2017.1291401

Terminski, B. (2013). Development-induced displacement and resettlement: Theoretical frameworks and current challenges. Development, 10, 101.

Terminski, B. (2014). Development-induced displacement and resettlement: causes, consequences, and socio-legal context. Columbia University Press.

Tsuma, D. N., \& Mwakera, M. (2016). Waitiki Land Beneficiaries. Daily Nation Newspaper. Nairobi: Nation Media Group. 
United Nations. (2016). Sustainable Development Goals. Retrieved from https://sustainabledevelopment.un.org/sdgs

Vanclay, F. (2017). Project-induced displacement and resettlement: from impoverishment risks to an opportunity for development? Impact Assessment and Project Appraisal, 35, 3-21. https://doi.org/10.1080/14615517.2017.1278671

Wikipedia. (2015). Circles of Sustainability. Retrieved from https://en.wikipedia.org/wiki/Circles_of_Sustainability

World Bank. (2013a). OP $4.12 \quad$ Involuntary Resettlement. Retrieved from https://policies.worldbank.org/sites/ppf3/PPFDocuments/Forms/DispPage.aspx?docid=1572\&ver=current

World Bank. (2013b). World Bank Group Support to Public-Private Partnerships. In Group IE (Ed.), Lessons from Experience in Client Countries, FY02-12. Washington: World Bank.

World Bank. (2015). Action Plan: Improving The Management of Safeguards And Resettlement Practices and Outcomes. Washington: World Bank Group.

Yamano, T., \& Deininger, K. (2005). Land conflicts in Kenya: causes, impacts, and resolutions. Foundation for Advanced Studies on International Development/National Graduate Institute for Policy Studies. The World Bank: 28.

\section{Copyrights}

Copyright for this article is retained by the author(s), with first publication rights granted to the journal.

This is an open-access article distributed under the terms and conditions of the Creative Commons Attribution license (http://creativecommons.org/licenses/by/4.0/). 